\title{
Farmers' Income and Land Cover Change at Lore Lindu National Park in Indonesia
}

\author{
Rustam Abdul Rauf ${ }^{1}$, Adam Malik ${ }^{2}$, Isrun ${ }^{1}$, Golar $^{2}$, Alimudin Laapo ${ }^{1}$, Marzuki $^{3}$, Sri Ningsih ${ }^{1}$, Arung Gihna \\ Mayapada $^{4}$ \& Effendy ${ }^{1}$ \\ ${ }^{1}$ Faculty of Agriculture, Tadulako University, Palu, Indonesia \\ ${ }^{2}$ Faculty of Forestry, Tadulako University, Palu, Indonesia \\ ${ }^{3}$ Faculty of Political and Social Sciences, Tadulako University, Palu, Indonesia \\ ${ }^{4}$ Faculty of Economics, Tadulako University, Palu, Indonesia \\ Correspondence: Effendy, Department of Agriculture Economics, Agriculture Faculty of Tadulako University, \\ Palu, Indonesia. E-mail: effendy_surentu@yahoo.com
}

Received: Sep. 13, 2018

doi:10.5539/mas.v12n12p41
Accepted: Sep. 25, 2018

Online Published: November 16, 2018

URL: https://doi.org/10.5539/mas.v12n12p41

\begin{abstract}
Lore Lindu National Park in Central Sulawesi is one of the protected areas. Although it is protected, many of its areas are experiencing pressure and disruption by human activities. The purpose of this research was to know the relationship between farmers' income and land cover change at Lore Lindu National Park. The research method was a participatory survey. Variables of incomes were sourced from farming and outside farming (forests). Data of land cover change were obtained using imagery in 2012, 2014 and 2016. The result of research is the average of farming income of IDR 1,387,077 (cocoa farming) and non-farm income of IDR 854,819 (forest honey, resin). In the last five years (2012-2016), the primary forest area decreased by 902.37 ha, while the secondary forest has shown an increase of 2,233.61 ha. The trend of land cover change was drastic, with change in the secondary dry land forest area from 6.9 ha (in 2012) to 2,240.5 ha (in 2016). The increased secondary forest area and the secondary forests have been converted into agricultural land and mixed gardens.
\end{abstract}

Keywords: income, land cover, lore lindu national park

\section{Introduction}

Lore Lindu National Park is officially designated as a national park by the Minister of Forestry and Plantation of the Republic of Indonesia based on the Decree of the Minister of Forestry and Estate Crops. 464 / Kpts-II / 1999 on June 23, 1999. Since its establishment, the area of Lore Lindu National Park was recorded at 217,991.18 ha, which covers the Sigi and Poso Regencies located in Central Sulawesi Province. Lore Lindu National Park has a unique diversity of flora and fauna which is found only on the island of Sulawesi. In addition, the existence of historical evidence of civilization and the culture of the surrounding community is another added value inherent in the Lore Lindu National Park.

Prior to being designated as a national park by the Government of the Republic of Indonesia, UNESCO first established the Lore Lindu area as part of the World Network of Biosphere Reserves (WNBR) in 1997. Lore Lindu National Park is expected to be an example of the development and implementation of sustainable development as the vision of WNBR UNESCO. This is because the interaction of local communities with natural resources in Lore Lindu National Park is still very strong from the past until now. This is proved by the existence of evidence of a megalithic civilization found around the Lore Lindu National Park area.

After the establishment of the Lore Lindu region as a national park, the conflict of interest between local communities and the managers of Lore Lindu National Park actually began to arise (Hidayat et al., 2007; Manullang, 1999). For local people, Lore Lindu National Park is their primary source of livelihood since the time of their ancestors. Restrictions on access to Lore Lindu National Park are tantamount to deprivation of the right to live and the closure of employment for local communities. Meanwhile, for the national park managers, Lore Lindu National Park is a legally protected area and should have restricted access. The unlimited use of the Lore Lindu National Park area can lead to land cover changes which might impact the destruction of flora and fauna habitats, micro-climate changes and decreased water supply. In addition, based on the mandate of Law no. 
41 of 1999 on Forestry and Law no. 18 of 2013 on Prevention and Eradication of Forest Destruction, illegal use of forest areas is a criminal act in forestry.

One of the efforts conducted by the Government of the Republic of Indonesia in dealing with conflicts between local communities and the managers of Lore Lindu National Park is to formulate a formal agreement between local communities and Lore Lindu National Park Office as the manager (Manullang, 1999). The agreement covers the rights and obligations of local communities and the managers of Lore Lindu National Park against Lore Lindu National Park area. It is undeniable that many of the local communities around the Lore Lindu National Park are taking advantage of the forest in Lore Lindu National Park solely to fulfill their daily needs, such as utilizing land in the Lore Lindu National Park as the main occupation. Consequently, community conservation agreements formulated between local communities and the managers of the Lore Lindu National Park should not ignore the socio-economic factors, especially the livelihoods of local communities.

Along with the increasing needs of society, human activities and intensity in utilizing natural resources undergo changes (Rudel et al., 2005). Changes in interaction between humans and nature are reflected through changes in land use and land cover (Caldas et al., 2007). The difference lies not in changes in land cover but changes in human capacity-building to convert land through agriculture, buildings and human settlements (Moran \& Ostrom, 2005). Previous research has revealed that changes in human activities that impact forest cover, such as agricultural land expansion, are influenced by economic factors (Geist \& Lambin, 2002; Lambin \& Meyfroidt, 2010). Several other researches have also revealed the importance of assessing land use change and land cover by considering socioeconomic aspects of society (da Silva et al., 2017; Prishchepov et al., 2012).

Based on the description above, this research aims to analyze empirically the changes in land cover in the area around Lore Lindu National Park due to changes in land use and local people's income related to the land cover change trend. Empirical analysis is an effective tool in testing the relationship between social and biophysical factors to changes in land cover (Moran \& Ostrom, 2005). This research contributes theoretically in terms of providing important insights into the complexity of human and environmental relationships by linking household-level data and remote sensing landscape results. In addition, this research also contributes practically in terms of providing input for the Government of the Republic of Indonesia regarding the formulation of an ideal conservation agreement between local communities and the managers of the Lore Lindu National Park. Conservation agreements between local communities and Lore Lindu National Park managers which do not harm either side help to achieve sustainable development goals as UNESCO aspires for Lore Lindu National Park as part of the world's biosphere reserves.

\section{Materials and Methods}

\subsection{Research Type}

This research is a descriptive research in which researchers describe the qualitative and quantitative data obtained related to changes in land cover and income of local communities. Qualitative data include data of land cover changes obtained by remote sensing, while the quantitative data include local income data obtained through participatory surveys.

\subsection{Research Area}

This research was conducted in all villages located in Lore Barat District, Poso Regency, Central Sulawesi Province. The Lore Barat District has six villages: Tuare, Lengkeka, Kageroa, Kolori, Lelio, and Tomihipi. The Lore Barat District is located to the south of the Lore Lindu National Park and borders it.

\subsection{Data Collection Method}

The data of this research include qualitative and quantitative data. Quantitative data is socio-economic data of local community, especially income, obtained through a participatory survey. The participatory survey was conducted for three months from October 2017 until December 2017. Quantitative data in this research is primary data because it is obtained directly by the researchers through several ways, such as: (1) questionnaire distribution, (2) conducting interviews, and (3) focus group discussions that are limited. The selected respondents and informants are representatives of the stakeholders spread in six villages in the Lore Barat District. Selection of respondents and informants was conducted by purposive sampling, snowball sampling and quota sampling techniques.

The purposive sampling technique is used to determine the respondents who can provide information about the criteria of poverty. The criteria of the respondents are: 
1. Respondents are the representatives of stakeholders in each village, such as community leaders, village government elements, group leaders, women representatives and community representatives who do gardening activities or benefit from forest products in the Lore Lindu National Park area.

2. Respondents are local indigenous people from the area (not migrants).

3. Respondents are willing to be interviewed.

The technique of snowball sampling and quota sampling is used to determine key informants. The key informants are explored to obtain in-depth information on the socio-economic aspects. In the snowball sampling technique, the initial informant who has been selected will determine the next informant who will convey the information required in this research. This is conducted to obtain consistent and accurate information. In addition, this research is also supported by data sourced through literature studies, other research documents and other relevant data related to changes in land cover and socio-economic aspects of local communities in conservation areas.

Qualitative data in this research is satellite image analysis data which produce land cover map. Image data is obtained through landsat, which is a remote sensing vehicle. Landsat image used is the image with the provisioning year 2012 and 2016.

\subsection{Data Analysis Method}

In this research, data related to the income of local community in the Lore Lindu National Park area is processed by using analysis of agricultural business income. The analysis of local community's income is used to inform local people's income from agricultural business and income from outside the farm (especially from forest products). The formula used is:

$$
I=T R-T C
$$

Explanation:

$\mathrm{I}=$ Income

$\mathrm{TR}=$ Total Revenue

$\mathrm{TC}=$ Total Cost

Meanwhile, analysis of land cover changes in Lore Lindu National Park is conducted by remote sensing interpretation technique which uses landsat image. Landsat image results are interpreted by classifying land cover types. The classification of land cover in Lore Lindu National Park is divided into six types, namely primary forest, secondary forest, shrubs, agricultural land and plantation, residential and water bodies.

Table 1. Descriptions of Land Cover Classification of Lore Lindu National Park

\begin{tabular}{|c|c|}
\hline Type & Description \\
\hline Primary forest of dry land & $\begin{array}{l}\text { All forest visibility in low areas, hills and mountains that have not yet } \\
\text { appeared in the logging, including natural low vegetation growing on } \\
\text { rocks. }\end{array}$ \\
\hline Secondary forest of dry land & $\begin{array}{l}\text { All forest visibility in low areas, hills and mountains that have been } \\
\text { logged over but not including industrial plantation forest, plantation or } \\
\text { agricultural land. }\end{array}$ \\
\hline Shrubs & $\begin{array}{l}\text { The former area of dryland forest that has been reforested by low } \\
\text { vegetation and does not show any more logging. }\end{array}$ \\
\hline Agricultural and plantation land & $\begin{array}{l}\text { All wetland agriculture activities are illustrated by embankment patterns } \\
\text { (except ponds and salt ponds) and entire plantation areas (either planted or } \\
\text { still empty). }\end{array}$ \\
\hline Settlements & Settlement areas are reflected from the pattern of a tight road path. \\
\hline Water body & $\begin{array}{l}\text { All aquatic sightings, including marine, rivers, lakes, reservoirs, coral } \\
\text { reefs and coastal mud. }\end{array}$ \\
\hline
\end{tabular}




\section{Results and Discussion}

\subsection{Local Community's Income in Lore Lindu National Park Area}

Data on the income of local community in the Lore Lindu National Park area, especially the community that lives in the Lore Barat District Poso Regency, was obtained through a participatory survey conducted at the end of 2017. Based on the results of participatory surveys, the obtained data showed that the majority of the community of the Lore Barat District work as cocoa farmers. The Central Bureau of Statistics of Poso Regency noted that the area of cocoa plantations in Lore Barat District per July 2017 reached 1,508 ha (BPS, 2017a). Meanwhile, the average income of Lore Barat District from cocoa farming is IDR 1,387,077 with average cultivated area of cocoa farming being one hectare per cocoa farmer. In addition, the community of Lore Barat District also relies on using natural resources in the forest, such as selling forest honey, becoming bamboo craftsmen, making palm sugar and making handicrafts from forest pandanus. These activities increase the main income of Lore Barat District from cocoa farming amounting to IDR 854,819.

Local community support for forest conservation depends on the socio-economic conditions of the community, especially in relation to the level of community welfare (Dwiprabowo et al., 2014). The results of this research indicate that cocoa farming is the main occupation of the majority of the community who live in Lore Barat District. Cocoa is indeed one of the main export commodities of Poso Regency and Central Sulawesi Province (DJPKP, 2016). According to Dwiprabowo et al. (2014), trade in forest products, agricultural products and plantations in both domestic and international markets will determine the direction of land use. Previous research has also found that cocoa is one of the main causes of deforestation in Lore Lindu National Park (Schwarze et al., 2006). Increasing or decreasing the price of cocoa commodities and other forest resources can encourage the opening of new land by the community of Lore Barat District.

The entire forest area in Lore Barat District is a protected forest area and a nature reserve and nature conservation area (BPS, 2017b). Massive deforestation of tropical forests into agricultural and plantation land has had a negative impact on biodiversity, land, degradation and the ability of the earth to support human living needs (Lambin et al., 2003). In addition, previous research results also reveal that deforestation in tropical forests is a major cause of global environmental change (Geist \& Lambin, 2002; Miet et al., 2002). Therefore, the government is required to formulate a forest conservation policy that remains concerned with the welfare of the community but does not damage the natural conservation around it (Schwarze et al., 2006).

\subsection{Land Cover Changes of Lore Lindu National Park}

The interpretation of results of satellite Landsat image in 2012 provides data on the extent of each land cover in each village located in Lore Barat District as follows.

Table 2. Land cover area in Lore Barat District of 2012

\begin{tabular}{llll}
\hline Number & Village & Land Cover Type & Broad (ha) \\
\hline 1 & Kageroa & Primary dryland forest & $2,924.00$ \\
2 & Kageroa & Dry land farms with shrubs & 662.35 \\
3 & Kageroa & Rice fields & 58.81 \\
4 & Kageroa & Water body & 14.37 \\
5 & Kolori & Primary dryland forest & $6,342.66$ \\
6 & Kolori & Dryland farming & $1,473.14$ \\
7 & Kolori & Dry land farms with shrubs & 197.80 \\
8 & Kolori & Rice fields & 273.35 \\
9 & Kolori & Water body & 65.35 \\
10 & Lelio & Primary dryland forest & $2,647.41$ \\
11 & Lelio & Dryland farming & 223.58 \\
12 & Lelio & Dry land farms with shrubs & 276.20 \\
13 & Lelio & Rice fields & 101.91 \\
14 & Lelio & Water body & 17.03
\end{tabular}




\begin{tabular}{llll}
15 & Lelio & Secondary dryland forest & 5.43 \\
16 & Lengkeka & Primary dryland forest & $5,813.88$ \\
17 & Lengkeka & Dryland farming & 217.54 \\
18 & Lengkeka & Dry land farms with shrubs & 278.07 \\
19 & Lengkeka & Water body & 21.16 \\
20 & Tomehipi & Primary dryland forest & 922.08 \\
21 & Tomehipi & Dryland farming & 17.24 \\
22 & Tomehipi & Dry land farms with shrubs & 56.29 \\
23 & Tuare & Primary dryland forest & $8,310.72$ \\
24 & Tuare & Dryland farming & 178.7 \\
25 & Tuare & Dry land farms with shrubs & 985.44 \\
26 & Tuare & Rice fields & 59.69 \\
27 & Tuare & Open Ground & 67.26 \\
28 & Tuare & Water body & 114.88 \\
29 & Tuare & Secondary dryland forest & 1.44 \\
\hline Total & & & $32,327.80$ \\
\hline
\end{tabular}

Source: Landsat Satellite Imagery, 2017 (processed)

While the interpretation of results of satellite Landsat image in 2016 for the same area of Lore Barat District is as follows.

Table 3. Land cover area in Lore Barat District 2016

\begin{tabular}{llll}
\hline Number & Village & Land Cover & Broad (Ha) \\
\hline 1 & Kageroa & Water Body & 14.37 \\
2 & Kageroa & Shrubs & 152.63 \\
3 & Kageroa & Primary Dryland Forest & $2,924.00$ \\
4 & Kageroa & Secondary Dryland Forest & 277.70 \\
5 & Kageroa & Mixed Dryland Farm & 232.01 \\
6 & Kageroa & Rice fields & 58.81 \\
7 & Kolori & Water body & 65.35 \\
8 & Kolori & Shrubs & 83.61 \\
9 & Kolori & Primary Dryland Forest & $6,342.66$ \\
10 & Kolori & Secondary Dryland Forest & 197.80 \\
11 & Kolori & Dryland Farming & 974.01 \\
12 & Kolori & Mixed Dryland Farm & 388.43 \\
13 & Kolori & Rice fields & 300.45 \\
14 & Lelio & Water body & 17.03 \\
15 & Lelio & Shrubs & 192.86 \\
16 & Lelio & Primary Dryland Forest & $2,652.84$ \\
17 & Lelio & Secondary Dryland Forest & 221.70 \\
18 & Lelio & Dryland Farming & 5.31 \\
19 & Lelio & Mixed Dryland Farm & 79.92 \\
20 & Lelio & Rice fields & 101.91 \\
21 & Lengkeka & Water body & 21.16 \\
22 & Lengkeka & Shrubs & 188.04 \\
23 & Lengkeka & Primary Dryland Forest & $5,813.88$ \\
24 & Lengkeka & Secondary Dryland Forest & 187.89 \\
25 & Lengkeka & Dryland Farming & 29.50 \\
& & &
\end{tabular}




\begin{tabular}{llll}
26 & Lengkeka & Mixed Dryland Farm & 90.18 \\
27 & Tomehipi & Primary Dryland Forest & 922.08 \\
28 & Tomehipi & Dryland Farming & 17.24 \\
29 & Tomehipi & Mixed Dryland Farm & 56.29 \\
30 & Tuare & Water body & 114.88 \\
31 & Tuare & Shrubs & 579.93 \\
32 & Tuare & Primary Dryland Forest & $7,402.92$ \\
33 & Tuare & Secondary Dryland Forest & $1,355.40$ \\
34 & Tuare & Dryland Farming & 21.19 \\
35 & Tuare & Mixed Dryland Farm & 116.92 \\
36 & Tuare & Rice Fields & 59.63 \\
37 & Tuare & Open Ground & 67.26 \\
\hline Total & & & $32,327.80$ \\
\hline
\end{tabular}

Source: Landsat Satellite Imagery, 2017 (processed)

Satellite imagery results show that there has been a decrease in land cover for primary forest type of dry land of $3 \%$ or 902.37 ha. In 2012, the area of primary forest in Lore Barat District was 26,960 ha. However, the area of primary forest in Lore Barat District in 2016 was reduced to 26,058 ha.

Compared to the satellite imagery result of 2012 and 2016, there is an increase in the area of secondary forest land covering of 2,233.61 ha. The area of secondary forest in Lore Barat District in 2012 was only 6.9 ha. However in 2016, it is recorded that the area of secondary forest in Lore Barat District increased significantly to 2,240 ha. This result means that there has been an increase in logging activities in the Lore Lindu National Park area, especially in Lore Barat District.

The results of this research indicate that there has been an increase in land clearing by the community over the past five years. Significant changes in land cover from primary forests into secondary forests during 2012-2016 allow communities around Lore Lindu National Park to convert secondary forests into agricultural and plantation land, including making rice fields. The conversion of land from forest to agricultural land in the Lore Lindu National Park will certainly have an adverse impact on the biodiversity of Lore Lindu National Park, which is dominated by the endemic flora and fauna of Sulawesi Island. In addition, Lore Lindu National Park is a tropical forest so that changes that occur in Lore Lindu National Park will have an impact on the global climate.

The change in land cover is primarily due to human activities, such as expansion of agricultural land, expansion of infrastructure and wood extraction (da Silva et al., 2017). Because they are caused by human activity, land cover changes are not only influenced by one factor but various complex factors, such as social and economic factors (Caldas et al., 2015). In the case of Lore Lindu National Park, the change in land cover is obviously caused by human activities. This is demonstrated by the significant increase in secondary forest area in Lore Barat District by 2016. According to Table 1, secondary forests are forests appearance that have logged over but not including industrial forest, plantation or agricultural land. Therefore, changes in land cover in Lore Lindu National Park can be ascertained as a result of human logging activities.

Analysis of land cover changes in Lore Lindu National Park area needs to consider the social and economic aspects of local communities because land use change in the area is caused by human activities. Previous research reveals that the deforestation process is influenced by the economic conditions of communities in relation to land use decisions (Caldas et al., 2007). In the context of community of Lore Barat District, land use decisions are influenced by the economic situation, especially the prices of cocoa commodities and other forest commodities. This is because the majority of the community in Lore Barat District rely for their livelihood on agricultural and forest products, especially cocoa. Data from the Directorate General of Plantation of the Ministry of Agriculture shows that the majority of cocoa produced in Central Sulawesi Province is the result of smallholder plantations rather than state and private plantations. In addition, the Ministry of Agriculture also noted that Poso Regency is the second region in Central Sulawesi province with the largest number of cocoa farmers.

Based on data from the Directorate General of Plantation at the Ministry of Agriculture, the prices of cocoa commodities in the world market have constantly increased during 2015-2017. This has led to an increase in the opening of agricultural and plantations land by the people of Poso Regency, including the Lore Barat District community, as illustrated by the results of landsat satellite images. According to Prishchepov et al. (2012), all 
land use decisions are made by local actors, i.e. the community around as landowners. However, the actions of local communities are limited by government policies and global market conditions (Geist et al., 2006).

On the one hand, the opening of agricultural/plantation land can increase cocoa production. Data from the Central Bureau of Statistics of Poso Regency shows that the main source of Gross Regional Domestic Product (GRDP) of Poso Regency is from agriculture and forestry sector. Therefore, the increasing cocoa production and increasing cocoa exports have an implication for the increasing GRDP of Poso Regency, Central Sulawesi Province GRDP and even national income and foreign exchange. This shows that not only do local communities survive from cocoa but also local government and central government still rely on cocoa as one of their main sources of income. This is in line with previous research which reveals that in countries with poor and middle income, such as Indonesia, conversion of natural habitat to common agricultural land frequently occurs.

On the other hand, increased cocoa production in Poso District through expansion of agricultural land/cocoa plantations adversely affects the natural condition of Lore Lindu National Park and even the global environmental conditions. The diversion of forest function to agricultural land has had an impact on changes in biodiversity and the loss of endemic species (Moran \& Ostrom, 2005). In addition, deforestation in tropical forests, such as Lore Lindu National Park, also leads to climate change through increased production of carbon gas (Schwarze et al., 2009). The rainfall also becomes unclear because of the changing landscape of agricultural land in rainforest areas, such as Lore Lindu National Park (Steffen, 2005).

\section{Conclusion}

This research reveals that land cover changes have occurred in the period of 2012-2016 in Lore Lindu National Park, more precisely in the Lore Barat District, Poso Regency. The result of landsat satellite images shows that there has been a significant increase in the area of secondary forests over the last five years. Meanwhile, the area of primary forest decreased. These results indicate that forests in the Lore Lindu National Park are undergoing deforestation.

Deforestation in forest areas in Lore Lindu National Park is mainly caused by human activities that utilize forest resources to survive and open new land for farming/gardening. This research reveals that most communities in Lore Barat District are cocoa farmers and make cacao farming as their main source of income. The average income of cocoa farmers in Lore Barat District is around IDR 1,300,000 per month with the assumption of one hectare of land for the production cocoa. Meanwhile, the average of other revenues sourced from utilizing forest resources is around IDR 800,000. Therefore, we conclude that the change of land cover in Lore Lindu National Park area is caused by the surrounding community's activity related to earning a living. We also suggest that land cover changes in Lore Lindu National Park are affected by global market conditions related to cocoa commodity prices which is one of the region's leading export commodities.

Although the Lore Lindu National Park area has been damaged on the grounds of survival, it cannot be justified. It is a biosphere reserve that must be protected and a tropical rain forest that must be preserved. Since most of the existing cocoa plantations in Poso Regency, including those in Lore Barat District, are plantations managed by the society, the government is expected to provide an understanding to the general public about the importance of environmental conservation. This research contributes importantly in terms of providing insight to the government to formulate the policies that can safeguard the interests of all parties, including taking into account the level of welfare of local community of Lore Lindu National Park. Nevertheless, this research still has limitations, especially in terms of availability of household data in time series. As a result, the research analysis cannot be conducted holistically.

\section{References}

BPS. (2017a). Luas Tanaman Perkebunan Menurut Kecamatan dan Jenis Tanaman di Kabupaten Poso (Hektar) $\begin{array}{lllll}\text { Tahun } 2015 . & \text { Badan }\end{array}$ https://posokab.bps.go.id/statictable/2017/07/11/51/luas-tanaman-perkebunan-menurut-kecamatan-dan-jenis -tanaman-di-kabupaten-poso-hektar-2015.html (Accessed on January 15, 2018).

BPS. (2017b). Luas Kawasan Hutan dan Perairan Menurut Kecamatan di Kabupaten Poso (Hektar) Tahun 2015. Badan Pusat Statistik

(BPS). https://posokab.bps.go.id/statictable/2017/07/11/52/luas-kawasan-hutan-dan-perairan-menurut-kecamatan-d i-kabupaten-poso-hektar-2015.html (Accessed on January 15, 2018).

Caldas, M. M., Goodin, D., Sherwood, S., Campos Krauer, J. M., \& Wisely, S. M. (2015). Land-cover change in the Paraguayan Chaco: 2000-2011. Journal of Land Use Science, 10(1), 1-18. https://doi.org/10.1080/1747423X.2013.807314 
Caldas, M., Walker, R., Arima, E., Perz, S., Aldrich, S., \& Simmons, C. (2007). Theorizing Land Cover and Land Use Change: The Peasant Economy of Amazonian Deforestation. Annals of the Association of American Geographers, 97(1), 86-110. https://doi.org/10.1111/j.1467-8306.2007.00525.x

da Silva, B., R. F., Batistella, M., Moran, E. F., \& Lu, D. (2017). Land Changes Fostering Atlantic Forest Transition in Brazil: Evidence from the Paraíba Valley. The Professional Geographer, 69(1), 80-93. https://doi.org/10.1080/00330124.2016.1178151

DJPKP. (2016). Statistik Perkebunan Indonesia 2015-2017: Kakao. Jakarta: Kementerian Pertanian. Direktorat Jenderal Perkebunan Kementerian Pertanian (DJPKP).

Dwiprabowo, H., Djaenudin, D., Alviya, I., \& Wicaksono, D. (2014). Dinamika Tutupan Lahan: Pengaruh Faktor Sosial Ekonomi. Yogyakarta: PT Kanisius.

Geist, H. J., \& Lambin, E. F. (2002). Proximate Causes and Underlying Driving Forces of Tropical Deforestation. BioScience, 52(2), 143. https://doi.org/10.1641/0006-3568(2002)052[0143:PCAUDF]2.0.CO;2

Geist, H., McConnell, W., Lambin, E. F., Moran, E., Alves, D., \& Rudel, T. (2006). Causes and Trajectories of Land-Use/Cover Change. Dalam E. F. Lambin \& H. Geist (Ed.), Land-Use and Land-Cover Change (hlm. 41-70). Berlin, Heidelberg: Springer Berlin Heidelberg. https://doi.org/10.1007/3-540-32202-7_3

Hidayat, Y., Sinukban, N., Pawitan, H., \& Tarigan, S. D. (2007). Dampak Perambahan Hutan Taman Nasional Lore Lindu Terhadap Fungsi Hidrologi Dan Beban Erosi (Studi Kasus Daerah Aliran Sungai Nopu Hulu, Sulawesi Tengah). Jurnal Ilmu Pertanian Indonesia, 12(2), 84-92.

Lambin, E. F., \& Meyfroidt, P. (2010). Land use transitions: Socio-ecological feedback versus socio-economic change. Land Use Policy, 27(2), 108-118. https://doi.org/10.1016/j.landusepol.2009.09.003

Lambin, E. F., Geist, H. J., \& Lepers, E. (2003). Dynamics of Land-Use and Land-Cover Change in Tropical Regions. Annual Review of Environment and Resources, 28(1), 205-241. https://doi.org/10.1146/annurev.energy.28.050302.105459

Manullang, S. (1999). Kesepakatan Konservasi Masyarakat dalam Pengelolaan Kawasan Konservasi. Departemen Kehutanan dan Perkebunan.

Miet, M., Zeller, M., \& Birner, R. (2002). Explaining Agricultural Land Use in Villages surrounding the Lore Lindu National Park in Central Sulawesi, Indonesia. Research Project on Stability of Rain Forest Margins, 4.

Moran, E. F., \& Ostrom, E. (2005). Seeing the Forest and the Trees: Human-Environment Interactions in Forest Ecosystems. Cambridge, Massachusetts: MIT Press.

Prishchepov, A. V., Radeloff, V. C., Baumann, M., Kuemmerle, T., \& Müller, D. (2012). Effects of institutional changes on land use: agricultural land abandonment during the transition from state-command to market-driven economies in post-Soviet Eastern Europe. Environmental Research Letters, 7(2), 024021. https://doi.org/10.1088/1748-9326/7/2/024021

Rudel, T. K., Coomes, O. T., Moran, E., Achard, F., Angelsen, A., Xu, J., \& Lambin, E. (2005). Forest transitions: towards a global understanding of land use change. Global Environmental Change, 15(1), 23-31. https://doi.org/10.1016/j.gloenvcha.2004.11.001

Schwarze, S., Erasmi, S., Priess, J. A., \& Zeller, M. (2009). Do National Park Reduce Deforestation? The Effectiveness of the Lore Lindu National Park in Indonesia. Research Project on Stability of Rain Forest Margins, 30.

Schwarze, S., Zeller, M., \& Nuryartono, N. (2006). Income sources, poverty, and forest encroachment: Implications for rural development policies in Central Sulawesi, Indonesia. Dalam Contributions of Agricultural Economics to Critical Policy Issues. Australia.

Steffen, W. L. (Ed.). (2005). Global change and the Earth system: a planet under pressure. Berlin. New York: Springer.

\section{Copyrights}

Copyright for this article is retained by the author(s), with first publication rights granted to the journal.

This is an open-access article distributed under the terms and conditions of the Creative Commons Attribution license (http://creativecommons.org/licenses/by/4.0/). 